Osteotomie am distalen Radius, Einbringen eines cortico-spongiösen Knochens und Fixierung mit einer schmalen T-Platte. Der Zugang muß entsprechend der Fehlstellung dorsal oder volar gewählt werden. Die Ergebnisse von 41 Patienten, an denen dieses Verfahren Anwendung fand, werden dargelegt.

Schlïsselwörter: Radiusfraktur - Fehlstellung - Korrekturoperation.

255. M. Dallek, U. Mommsen, K. H. Jungbluth, Hamburg: Die supracondyläre Oberarmfraktur im Kindesalter. Ihre Behandlung und Ergebnisse nach der Methode von Blount.

Manuskript nicht eingegangen

\title{
256. Grenzindikationen zwischen konservativer und operativer Frakturbehandlung am wachsenden Skelet
}

\author{
F. Hahn, R. Tiedtke, R. Rahmanzadeh und I. Nierlich
}

Abteilung für Unfall- und Wiederherstellungschirurgie am Klinikum Steglitz der Freien Universität Berlin, Hindenburgdamm 30, D-1000 Berlin 45

\section{Borderline Indications Between Conservative and Operative Treatment of Fractures of the Growing Skeleton}

Summary. For fractures in children, there are few objective operating indications (e.g. epiphysial fractures, traction fractures, etc.). The choice of treatment procedures is otherwise subjective (e.g. in polytrauma, insufficient reposition or retention). Our own follow-up examination results (289 cases, humerus fractures and femur shaft fractures, up to 9 years of observation) allow the following statements regarding the frequency of operation: 1 . The differentiated approach is advantageous ( 3 or 4 methods per type of fracture). 2 . If there is doubt, a decision should be made in favor of operation since there are hardly any counterindications, the degree of risk involved is on the whole low and the stay in hospital is shorter. However, not many conservative methods are free of risk. (The extension treatment of the upper extremity is entirely dispensable.)

Key words: Fractures of the growing skeleton - Differentiated indications - Follow-up examinations.

Zusammenfassung. Bei kindlichen Frakturen gibt es einige wenige objektive Operationsindikationen (z. B. Epiphysenfrakturen, Traktionsfrakturen usw.). Ansonsten ist die Wahl des Behandlungsverfahrens dem subjektiven Ermessen unterworfen (z. B. beim Polytrauma, bei ungenügender Reposition oder Retention). Die eigenen Nachuntersuchungsergebnisse (289 Fälle, Humerusfrakturen und Femurschaftfrakturen, bis zu 9 Jahre nach Beobachtungszeit) erlauben die folgenden Feststellungen bezüglich der Operationshäufigkeit: 1. Ein differenziertes Vorgehen ist vorteilhaft ( 3 oder 4 Behandlungsmethoden pro Frakturart). 2. Im Zweifel sollte die Entscheidung zugunsten der Operation fallen, da es kaum Kontraindikationen gibt, das Operationsrisiko gering ist und ein kürzerer Hospitalaufenthalt möglich ist. Demgegenüber sind viele konservative Verfahren auch nicht risikofrei. (Die Extensionsbehandlung an der oberen Extremität erscheint überhaupt entbehrlich.)

Schliisselwörter: Frakturen am wachsenden Skelet - Differenzialindikationen - Nachuntersuchungen.

\section{Funktionelle Behandlung von Oberarmschaftbriichen mit Sarmiento-Kunststoffmanschette}

\section{G. Wasmer, O. Wörsdörfer, G. Lob und C. Burri}

Klinik für Unfallchirurgie, Hand-, Plastische und Wiederherstellungschirurgie der Universität Ulm, Steinhövelstraße 9, D-7900 Ulm

\section{Functional Treatment of Fractures of the Shaft of the Humerus with the Sarmiento Brace}

Summary. With a few exceptions, we only treat fractures of the shaft of the humerus with a functional method consisting of a plastic sleeve, as indicated by Sarmiento. After reduction and detumescence of the swelling in an upper-arm cast for 5-10 days, a Sarmiento Brace is fit and functional body exercises started. Out of 31 consecutive fractures of the shaft of the humerus, 26 were treated by means of a Sarmiento Brace. In all cases bony consolidation was achieved in 6-8 (in one case in 11) weeks without secondary complications. A slight shift of the axis was occurred in two-thirds of the cases. However, the functional result was thoroughly good.

Key words: Fractures of the humerus shaft - Functional treatment - Sarmiento brace. 